\title{
意識集中時における脳波の振幅変化を用いたコミュニケーションの基礎的検討 Possibility of brain computer interface using EEG amplitude attenuation during mental task
}

\author{
○西藤 聖二 ${ }^{1}$, 中川 雅史 ${ }^{1}$, 田中 正吾 ${ }^{1}$ \\ 1. 山口大学大学院理工学研究科 \\ OSeiji Nishifuji ${ }^{1}$, Masashi Nakagawa ${ }^{1}$ and Shogo Tanaka ${ }^{1}$ \\ 1. Graduate School of Science and Engineering, Yamaguchi University
}

\section{1. はじめに}

重度身障者のためのコミュニケーションツールを目的として、脳 波を用いたブレイン・コンピュータ・インターフェース(BCI)の開 発・研究が盛んに行われている。 BCI に用いる脳波の成分として は事象関連電位が主であるが、その他にも視覚誘発電位や $1 \mathrm{~Hz}$ 以下の低周波成分など、種々の脳波成分が検討されている。

しかしながら、実用的な観点からは、いずれの脳波成分も使用 者の意志・要求による変化が小さく、検出が容易でないことや、変 化の再現性が十分でないなど、何らかの課題が残されている。 のため、使用ストレスの少ない BCI の開発に向けて、検出すべき 脳波成分の検討が急がれている。1)

本研究では、意識集中や精神作業による $\alpha$ 波 $(8 \sim 13 \mathrm{~Hz})$ の抑 制に注目している。 $\alpha$ 波は安静閉眼時脳波の支配的な成分で信 号対雑音比が大きいため、種々の雑音の混入が不可避な使用環 境においても容易に検出可能である。さらに、トレーニングを行わ ずとも、意識集中等によって $\alpha$ 波の振幅を抑制することができる ため、使用者の精神的負担感も比較的小さいという特質がある。

一方、 $\alpha$ 波は安静状態でも大きな摇らぎを示すため、自然変 動と意志による抑制を適切に識別することが課題である。また、意 志による $\alpha$ 波の振幅変化の大小に相当な個人差があることも、問 題点として挙げられている。

そこで、本研究では、暗算や記憶イメージの想起などの精神作 業を行ったときの $\alpha$ 波の振幅変化を、安静時 $\alpha$ 波の統計的性質 (平均、標準偏差)に基づいて評価することにより、 $\alpha$ 波の BCI の適用の可能性と課題を検討したので、報告する。

\section{2. 方法}

2.1 実験 $21 \sim 24$ 歳の健常者 16 名（男 15 名、女 1 名）を 対象として、電磁シールドルーム内で、覚醒閉眼時の脳波を 国際 10-20 電極配置法に従って、頭部全体の15 部位から両耳 架を連結して基準電極とした単極導出法により導出した。脳 波は脳波計（日本光電製 $\mathrm{EEG}-5532$ 、ゲイン 86dB）で増幅後、 $\mathrm{PC}$ で $200 \mathrm{~Hz} / \mathrm{ch}, 12$ ビットの分解能で離散值化した。実験に 際しては、ヘルシンキ宣言の主旨に則って事前に被験者から 実験の同意を得た。

被験者には以下のような課題（最大作業時間 30s）を与え、 作業前約 10s から作業終了時までの脳波記録を採取した。

1. 暗算： 2 桁の掛け算

2. しりとり：15 個に達するまで継続

3. 写真の想起 : 事前に写真を記憶し、作業時に想起

4. 人物・物の想起 (1)：好きな人やものを想起

5. 人物・物の想起 (2)：嫌いな人やものを想起 なお、作業中には被験者は閉眼状態を継続し、できるだけ体 を動かさないように指示された。

2.2 解析 本研究では Complex Demodulation 法 (CDM)を用 いて、 $\alpha$ 波のエンベロープ（振幅）の瞬時值を推定した。得 られた振幅の推定值は常時変動するため、安静時 $\alpha$ 波 (40s) の平均振幅 $\mu_{r}$ および標準偏差 $\sigma_{r}$ を用いて、作業時に振幅がど の程度抑制されたかを、以下の手順で調べた。
[1]適宜設定したウィンドウ $(2 \mathrm{~s})$ における振幅抑制度の評価 值 $J=\sum_{k=1}^{n}\left(A_{k}-\mu_{r}\right) /\left(n \sigma_{r}\right)$ を求める。ここで $n$ はウィンド ウ長分のデータ数、 $A_{k}$ は作業時の瞬時振幅値である。

[2] 作業時間内 $(10 \sim 20 \mathrm{~s})$ で $J \leq-\kappa_{1}$ となる割合 $P_{t}$ を求める。 $P_{t}$ は作業時における低振幅時間の割合を示す。

[3] 安静時において同様の量 $P_{r}$ を求め、両者の比 $R_{p}=P_{t} / P_{r}$ を得る。 $R_{p} \geq \kappa_{2}$ の場合を「認知作業に伴う低振幅状態」 として、安静時と区別する。

$\kappa_{1}, \kappa_{2}$ は経験的に求め、 $\kappa_{1}=0.9, \kappa_{2}=2.0$ とした。すなわち、 低振幅時間の割合が安静時の 2 倍以上になる場合を検出した。

\section{3. 結果}

Fig. 1 に暗算時の評価值 $J$ の時間変化を示す（被験者 A)。 作業開始数秒前から評価值の減少が始まっているが、作業開 始までは安静時の摇らぎの範囲内に収まっている。さらに作 業開始後は急激に振幅が低下して、しきい值 $\kappa_{1}$ を大きく下回 る。その後、評価值は増減を繰り返すが、2 度目の低レベル の状態を脱した後、作業終了に伴って安静状態 ( $J=0$ 付近) に戻る。作業中の 20 秒間中、低振幅時間が約半分を占め、 $R_{p}=13$ となって「認知作業による低振幅状態」と判定された。

本研究では、1. 暗算〜3. 写真想起の場合に被験者の約 7 割 で低振幅状態を検出した。一方、4. と 5. の人物・ものの想 起では、識別できたのは被験者の 4 割以下に留まった。

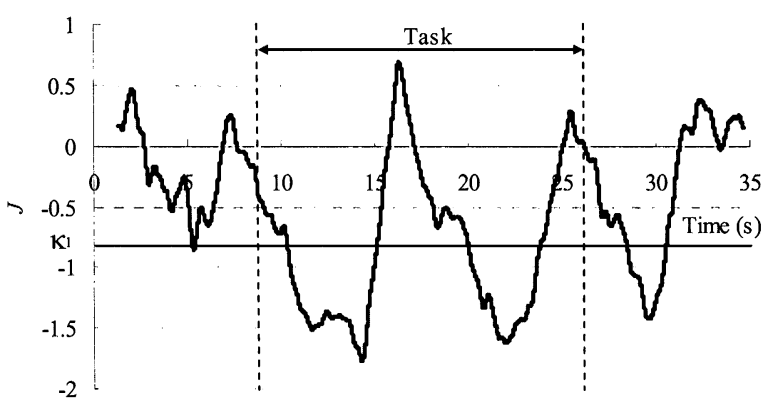

Fig. 1 振幅評価值 $J$ の時間変化

\section{4. おわりに}

本研究では $\alpha$ 波の BCI への応用の可能性を探るために、精 神作業に伴う $\alpha$ 波の振幅抑制状態を安静時と識別する方法を 提案して、その有効性を検討した。その結果、暗算やしりと り、写真の想起ではまずまずの識別率が得られた。これらの 課題は、被験者にとって比較的集中しやすいことが理由の一 つとして考えられる。ただし、実用的な観点からは、写真の 想起のような、より簡単な課題で識別率を上げることが必須 であり、実験および解析の両面で改善すべき点はなお多い。

\section{参考文献}

1) J. R. Wolpaw et al., Brain-computer interfaces for communication and control. Clin. Neurophysiol., 2002; 113: 767-791. 